\title{
Anti-proliferative of physcion 8-O- $\beta$ - glucopyranoside isolated from Rumex japonicus Houtt. on A549 cell lines via inducing apoptosis and cell cycle arrest
}

\author{
Qi-Chao Xie* and Yu-Peng Yang
}

\begin{abstract}
Background: Lung cancers are leading causes of cancer death, and Rumex japonicus has been traditionally used in folk medicine as anti-microorganic, anti-inflammatory and anti-tumor agents. This study was designed to investigate the anti-proliferative activity of physcion 8-O- $\beta$-glucopyranoside (PG) isolated from Rumex japonicus Houtt. on A549 cell lines.

Methods: In our present study, PG was isolated and identified from the ethanol extracts of R. japonicus. MTT method was used to evaluate the anti-proliferative activity of PG on A549 cell lines, and cell cycle distribution assay, apoptosis assay, and western blot analysis in vitro were used to explore the possible mechanisms.

Results: From the results of our present study, cell viability was obviously inhibited by PG, in a dose- and time-dependent manner. Our results also suggested that the anti-proliferative effect of PG was related to cell cycle arrest at the G2/M phase through repression of cdc2 and Cyclin B1 protein expression. In addition, the results of apoptosis assay and western blot analysis indicated that the anti-proliferative activity could be related to apoptosis via up-regulating the expressions of Bax, caspase-3 and caspase-7, and down-regulating the expressions of Bcl-2.

Conclusions: In conclusion, the PG has significant anti-proliferative activity on A549 cell lines, and the possible mechanism was related to cell cycle arrest at the G2/M phase, and apoptosis via the regulations of $\mathrm{Bax}$, $\mathrm{BCl}-2$, and caspase-3 and caspase-7.
\end{abstract}

Keywords: Physcion 8-O-ß-glucopyranoside, Rumex japonicus Houtt, Anti-proliferative activity, Apoptosis, Lung cancer

\section{Background}

Lung cancers are the leading causes of cancer death worldwide. Lung cancers are commonly classified as small cell lung cancer (SCLC) and non-small cell lung cancer (NSCLC), and NSCLC constitutes approximately $80 \%$ of the lung cancer cases [1-3]. It's well known that smoking is the predominant etiologic risk factor for lung cancers, and polycyclic aromatic hydrocarbons are reported as the major causative agents among cigarette smoke components for lung cancer development [2,4]. Currently, chemotherapy is still the major therapeutic method for lung cancers after surgery resection, and this

\footnotetext{
* Correspondence: xieqctmmu@126.com

Department of Oncology, the Second Affiliated Hospital, Third Military Medical University, 183 Xinqiao main street, Chongqing 400037, China
}

treatment can significantly improve the survival rate of patients $[5,6]$. However, the long-term survival rate remains low and the 5-years survival rate after surgery is less than $70 \%[5,7]$. Besides, the synthetic drugs, which have severe side effects, are commonly the only option for cancer chemotherapy $[8,9]$. Therefore, it is important to search for new reliable therapeutic agents with low toxicity to lung cancer treatment. Traditional Chinese medicine (TCM) has been used for cancer treatment for a long time either being used alone or in combination with western medicines [10]. And natural products isolated from the plants are important sources of cancer therapies [11,12].

Rumex japonicus Houtt, a perennial herb plant belonging to the family Polygonaceae, is widely distributed 
throughout China (known as Yang-Ti, in Chinese). It has been traditionally used in folk medicine as antimicroorganic, purgative, anti-inflammatory and anti-tumor agents [13-15], and $R$. japonicus contains a large number of anthraquinones, oxanthrones, and flavones $[13,14,16]$. However, there has been no report regarding the active anti-tumor compounds isolated from $R$. japonicus and its possible mechanisms thus far. Physcion 8-O- $\beta$ glucopyranoside (PG), one of the major bioactive compounds presented in the $R$. japonicus, is an anthraquinones. The aim of the present study is to investigate the antiproliferative activity of PG based on our preliminary experiments.

\section{Methods}

\section{Plant material}

Rumex japonicus Houtt was purchased from the Chuqimen Market of Traditional Chinese Herbs and identified as the roots of $R$. japonicus by the department of Traditional Chinese Medicine of the Second Affiliated Hospital, Third Military Medical University. A vouncher specimen of $R$. japonicus (No. RJ2010-09) was deposited at the Second Affiliated Hospital, Third Military Medical University.

\section{Cells culture}

Human lung cancer cell line A549, human Myeloid Leukemia cell Line IL-60, human breast cancer cell line MCF-7, colonic carcinoma cell Line HCT-8, human cervical carcinoma cell line Hela, and human hepatoma cell line HepG2 were purchased from American Type Culture Collection. The cells were cultured in RPMI1640 medium (Gibco, CA, USA) with 10\% fetal bovine serum (Gibco, CA, USA) and antibiotics (100 U/mL penicillin and $100 \mu \mathrm{g} / \mathrm{mL}$ streptomycin). The cell line was kept at $37^{\circ} \mathrm{C}$ in $5 \% \mathrm{CO}_{2} / 95 \%$ air.

\section{Chemicals}

Silica-gel (100-200, 200-300 mesh) was purchased from Qingdao Haiyang Chemical Co., Ltd. (Qingdao, China); methanol $(\mathrm{MeOH})$ [analytical reagent grade (AR)], Petroleum ether (AR), ethyl acetate (AR), n-butanol (AR) were purchased from Sinopharm chemical reagent Co., Ltd. (Shanghai, China); Sephadex LH-20 was purchased from HEE Co., Ltd. (Beijing, China). The RPMI 1640 media and fetal bovine serum (FBS) were purchased from Invitrogen (Carlsbad, USA). Methylthiazdyldiphenyl-tetrazolium bromide (MTT) and dimethyl sulfoxide were purchased from Sigma (NY, USA). Human phospho-Cdc2 (Tyr15), Cdc2, Cyclin B1, caspase-3, caspase-7, Bax and Bcl-2 monoclonal antibody and Annexin V/FITC kit was purchased from Beyotime Institue of Biotechnology (Haimen, China). All other chemicals used in this study were of analytical reagent grade.

\section{Extraction, isolation and preparation of total extracts and pure compounds}

Dried $R$. japonicus $(50 \mathrm{~kg}$ ) was powdered and extracted with $75 \%$ aqueous ethanol by reflux three times (each extraction period lasted $3 \mathrm{~h}$ ). The solvent was evaporated under vacuum to afford crude total extract of $R$. japonicus. Then the extract was suspended in water and partitioned with petroleum ether, chloroform, ethyl acetate, and aqua-saturated $n$-butanol successively. The $n$-butanol fraction was subjected to repeated column chromatography over silica gel (100-200 mesh) column chromatography and eluted with ethyl acetate-methanol (20:1 1:2). Then, similar fractions were combined based on the basis of thin layer chromatography analysis (TLC), and 7 fractions (I-VII) were obtained. By using a series of chromatographic techniques, such as silica gel column chromatography (200-300 mesh) and Sephadex LH-20 chromatography, the compound was isolated from fractions III (140 mg) [16,17].

\section{MTT reduction assay}

Cells $\left(1 \times 10^{4} / 0.2 \mathrm{~mL}\right)$ were seeded in 96-well plates and treated on the following day with PG ranged from $5 \mu \mathrm{g} / \mathrm{ml}$ to $80 \mu \mathrm{g} / \mathrm{ml}$ (for 24 or $48 \mathrm{~h}$, respectively). After that, MTT assay was carried out [9] and optical density (OD) was read at $570 \mathrm{~nm}$ using a 96-well plate reader. Since reduction of MTT only occurred in metabolically active cells, the level of activity was a measure of the viability of the cells. The inhibition rate was calculated according to the following formula: $\left(\mathrm{OD}_{\text {control }}-\mathrm{OD}_{\text {treatment }}\right) / \mathrm{OD}_{\text {control }} \times 100 \%$. The $\mathrm{IC}_{50}$ (inhibitor concentration at which occurs $50 \%$ inhibition of proliferation) value was calculated using Bliss method by SPSS software.

\section{Cell cycle distribution assay}

A549 Cells $\left(5 \times 10^{5} / \mathrm{mL}\right)$ were seeded in 6-well plates. On the following day, the cells were treated with 20,40 and $80 \mu \mathrm{g} / \mathrm{mL}$ of PG for $24 \mathrm{~h}$, or treated with $80 \mu \mathrm{g} / \mathrm{mL}$ of PG for 12, 24, $48 \mathrm{~h}$, respectively. Then, cells were trypsinized, washed with Phosphate Buffered Saline (PBS) and fixed in $1 \mathrm{~mL}$ of ice-cold $70 \%$ ethanol overnight at $4^{\circ} \mathrm{C}$. The cells were concentrated by removing ethanol and treated with $0.01 \%$ Dnase-free RNase A for $10 \mathrm{~min}$ at $37^{\circ} \mathrm{C}$. Cellular DNA was stained with $0.05 \%$ propidium iodide (PI) for $20 \mathrm{~min}$ at $4^{\circ} \mathrm{C}$ in darkness. The cell cycle distribution was detected with flow cytometry (FCM) on a FACScalibur cytometer (Becton Dickinson, US). The percentage of cells at $G_{1}, S$, or $G_{2} / M$ phase was documented using ModFit software (Becton Dickinson, US).

\section{Apoptosis assay}

Two methods were used for apoptosis assays. Firstly, A549 Cells $\left(5 \times 10^{5} / \mathrm{mL}\right)$ were seeded in 6 -well plates. On the 
Table $1 \mathrm{IC}_{50}$ of the total extracts of Rumex japonicus Houtt

\begin{tabular}{|c|c|c|c|c|c|c|}
\hline Cells & IL-60 & A549 & MCF-7 & HCT-8 & Hela & HepG2 \\
\hline $\mathrm{IC}_{50}(\mu \mathrm{g} / \mathrm{mL})$ & $127.43 \pm 3.12$ & $44.19 \pm 1.08$ & $>150$ & $>150$ & $>150$ & $146.25 \pm 3.97$ \\
\hline
\end{tabular}

Cells were treated with PG for $48 \mathrm{~h}$, and the MTT assay were determined to obtain the $\mathrm{IC}_{50}$.

following day, the cells were treated with 20, 40 and $80 \mu \mathrm{g} / \mathrm{mL}$ of PG. 48 hours later, cells were trypsinized, washed with PBS and stained using an Annexin V/FITC kit. The cells were detected with flow cytometry (FCM) on a FACScalibur cytometer (Becton Dickinson, US).

Secondly, the cells $\left(1 \times 10^{4} / 0.2 \mathrm{~mL}\right)$ were seeded in 96 well plates and then treated with $100 \mathrm{nM}$ of Ac-DEVD$\mathrm{CHO}$ (caspase inhibitor) [18] for $3 \mathrm{~h}$. The cells were treated with PG $(20,40$ and $80 \mu \mathrm{g} / \mathrm{mL})$ for $48 \mathrm{~h}$. Cells survival was determined by MTT assay to evaluate whether the anti-proliferative effect of PG was related to apoptosis through caspase pathway that lead to apoptotic.

\section{Western blot analysis}

A549 Cells $\left(5 \times 10^{5} / \mathrm{mL}\right)$ were seeded in 6-well plates. On the following day, the cells were treated with 20, 40 and $80 \mu \mathrm{g} / \mathrm{mL}$ of PG. 48 hours later, cells were harvested and homogenized with lysis buffer. Total cell protein was extracted and the protein concentration was determined using BCA Protein Assay Kit (Beyotime Institue of Biotechnology, Haimen, China). Subsequently, the total cellular protein was separated by $12 \%$ SDS-polyacrylamide gel electrophoresis (SDS PAGE), and transferred to PVDF membranes (Millipore USA). Membranes were blocked with $5 \%$ fat-free milk in TBST $(10 \mathrm{mM}$ Tris- $\mathrm{HCl}, 0.1 \mathrm{M}$
$\mathrm{NaCl}_{2}, 0.1 \%$ Tween 20, $\mathrm{pH}$ 7.4), and incubated with phospho-Cdc2 (Tyr15), Cdc2, Cyclin B1, caspase-3, caspase-7, Bax and Bcl-2 monoclonal antibodies, respectively. Protein bands were detected by incubating with HRP-conjugated secondary antibodies (Beyotime Institue of Biotechnology, Haimen, China) and visualized by BeyoECL plus Kit, and then immunoblotting signals were scanned and quantitated using a ChemiDoc XRS gel imaging system (Bio-Rad USA). Fold changes of protein levels were determined by using Bio-Rad quantity one software and compared to the protein expression of $\beta$-actin.

\section{Statistical analysis}

All results were presented as mean \pm standard deviation (SD) from at least three independent experiments. Statistical analyses were performed using the two-tailed Student's $t$-test. Differences with the $\mathrm{p}$ value less than 0.05 was considered statistically significant.

\section{Results}

$I_{50}$ values of the total extract of $R$. japonicus on the six human cancer cell lines

The investigation on anti-proliferative activities of the total extract from $R$. japonicus was conducted, and the results are represented in Table 1 . The data demonstrated

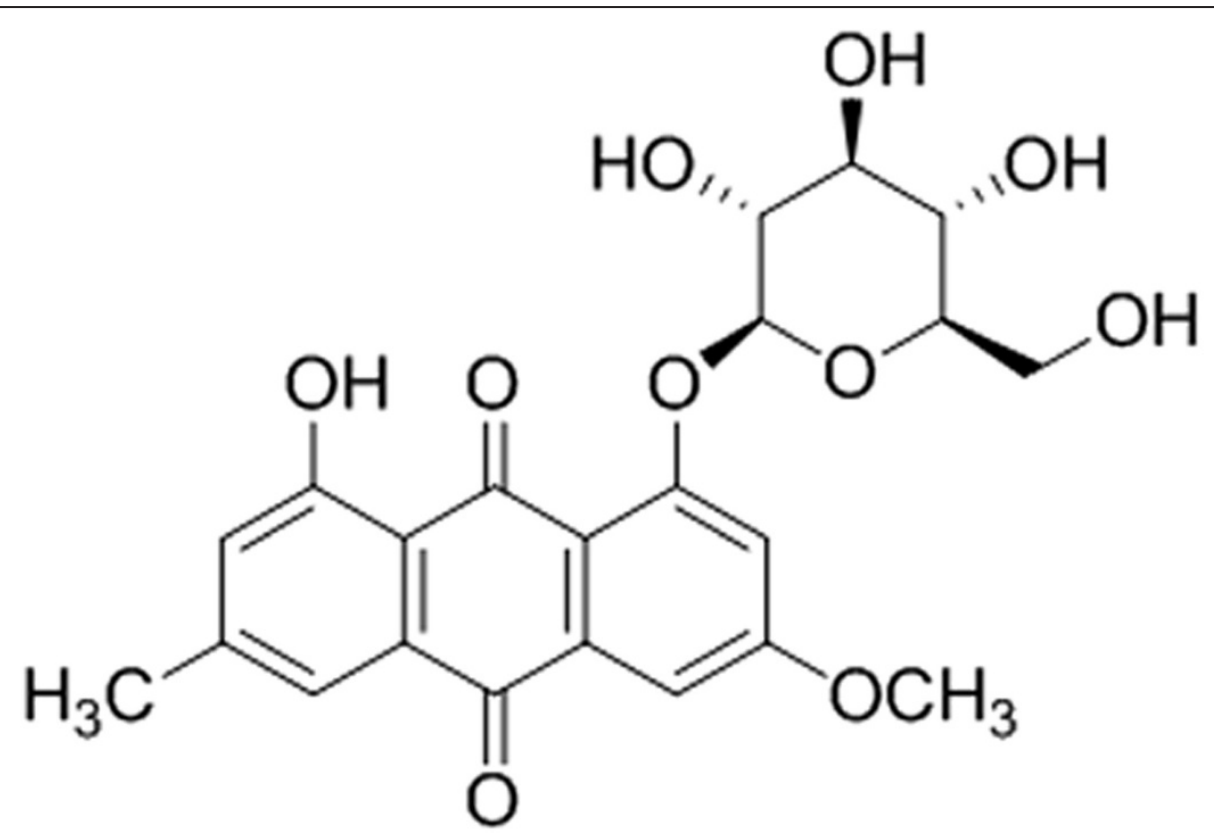

Figure 1 Molecular structure of physcion 8-O- $\beta$-glucopyranoside. 
Table $2^{1} \mathrm{H}$ NMR (600 MHz) and ${ }^{13} \mathrm{C}$ NMR (150 MHz) data of compound 1 in DMSO- $d_{6}(\delta, \mathrm{ppm})$

\begin{tabular}{cccccc}
\hline Position & $\boldsymbol{\delta}_{\mathbf{H}}(\mathbf{J}$ in Hz) & $\boldsymbol{\delta}_{\mathbf{c}}$ & Position & $\boldsymbol{\delta}_{\mathbf{H}}(\mathbf{J} \mathbf{~ i n ~ H z})$ & $\boldsymbol{\delta}_{\mathbf{c}}$ \\
\hline 1 & $12.87(\mathrm{~s},-\mathrm{OH})$ & 161.6 & $8 \mathrm{a}$ & 114.5 \\
2 & $7.17(\mathrm{brs})$ & 125.1 & $9 \mathrm{a}$ & 114.4 \\
3 & & 147.1 & $10 \mathrm{a}$ & 136.4 \\
4 & $7.46(\mathrm{~d}, 1.6 \mathrm{~Hz})$ & 119.3 & $1^{\prime}$ & 100.9 \\
5 & $7.38(\mathrm{~d}, 2.6 \mathrm{~Hz})$ & 106.7 & $2^{\prime}$ & 73.3 \\
6 & & 164.7 & $3^{\prime}$ & & 77.2 \\
7 & $7.19(\mathrm{~d}, 2.6 \mathrm{~Hz})$ & 107.5 & $4^{\prime}$ & & 69.8 \\
8 & $3.74(\mathrm{~s})$ & 161.1 & $5^{\prime}$ & & 76.8 \\
9 & & 186.4 & $6^{\prime}$ & & 60.8 \\
10 & & 181.7 & $3-\mathrm{CH}_{3}$ & $2.39(\mathrm{~s})$ & 21.3 \\
$4 \mathrm{a}$ & & 132.1 & $6-\mathrm{OCH}_{3}$ & $3.97(\mathrm{~s})$ & 56.1 \\
\hline
\end{tabular}

that, the total extract displayed moderate anti-proliferative activities against IL-60 and HepG2 cell lines $\left(\mathrm{IC}_{50}\right.$ were $127.43 \pm 3.12$, and $146.25 \pm 3.97 \mu \mathrm{g} / \mathrm{mL}$, respectively); furthermore, no obvious anti-tumor effect was observed on the MCF-7, HCT-8, and Hela cells $\left(\mathrm{IC}_{50}>150 \mu \mathrm{g} / \mathrm{mL}\right)$; however, the total extract showed a significant cytotoxic activity on the A549 cell line with the $\mathrm{IC}_{50}$ less than $50 \mu \mathrm{g} / \mathrm{mL}\left(\mathrm{IC}_{50}=44.19 \pm 1.08 \mu \mathrm{g} / \mathrm{mL}\right)$.

Analysis of the compound isolated from $R$. japonicas The compound isolated from the Rumex japonicus Houtt. was identified as physcion 8-O- $\beta$-glucopyranoside
$[16,17]$ (Figure 1, Table 2). The spectral data of the compound were as follows: Yellow needle crystals; melting point (m.p.) $231-233^{\circ} \mathrm{C}$; electrospray ionisation tandem mass spectrometry (ESI-MS) $m / z: 445.1[\mathrm{M}-\mathrm{H}]^{-}$, and it showed the molecular ion at $\mathrm{m} / z 446$, which was in accordance with the molecular formula $\mathrm{C}_{22} \mathrm{H}_{22} \mathrm{O}_{10}$. The ${ }^{1} \mathrm{H}$-NMR and ${ }^{13} \mathrm{C}$-NMR information was shown in Table 2.

\section{Physcion 8-O- $\beta$-glucopyranoside inhibits the viability of} A549 cells in dose- and time-dependent manners

To evaluate the cytotoxic effect of PG on A549 cell and get the $\mathrm{IC}_{50}$ value, the viability of cells treated with different concentrations (ranging from 5 to $80 \mu \mathrm{g} / \mathrm{mL}$ ) of PG was measured using MTT test. The result showed that PG reduced cell survival in a dose- and timedependent manner (Figure 2). The $\mathrm{IC}_{50}$ of PG to A549 cell lines was $53.01 \mu \mathrm{g} / \mathrm{mL}$ at $24 \mathrm{~h}$ and $27.31 \mu \mathrm{g} / \mathrm{mL}$ at $48 \mathrm{~h}$, respectively. Based on the results, the concentration of 20,40 and $80 \mu \mathrm{g} / \mathrm{mL}$ were selected and used in the subsequent experiment.

\section{PG induced cell cycle arrest at $G_{2} / M$ phase in dose- and} time-dependent manners

Cell cycle arrest was the major reason of cell death induced by anti-tumor drugs. Cell cycle regulation was important for cell proliferation [19-21]. To examine whether the anti-proliferative effect of PG was related to cell cycle arrest, the cell cycle distribution was tested. The results showed 20,40 and $80 \mu \mathrm{g} / \mathrm{mL}$ of PG had

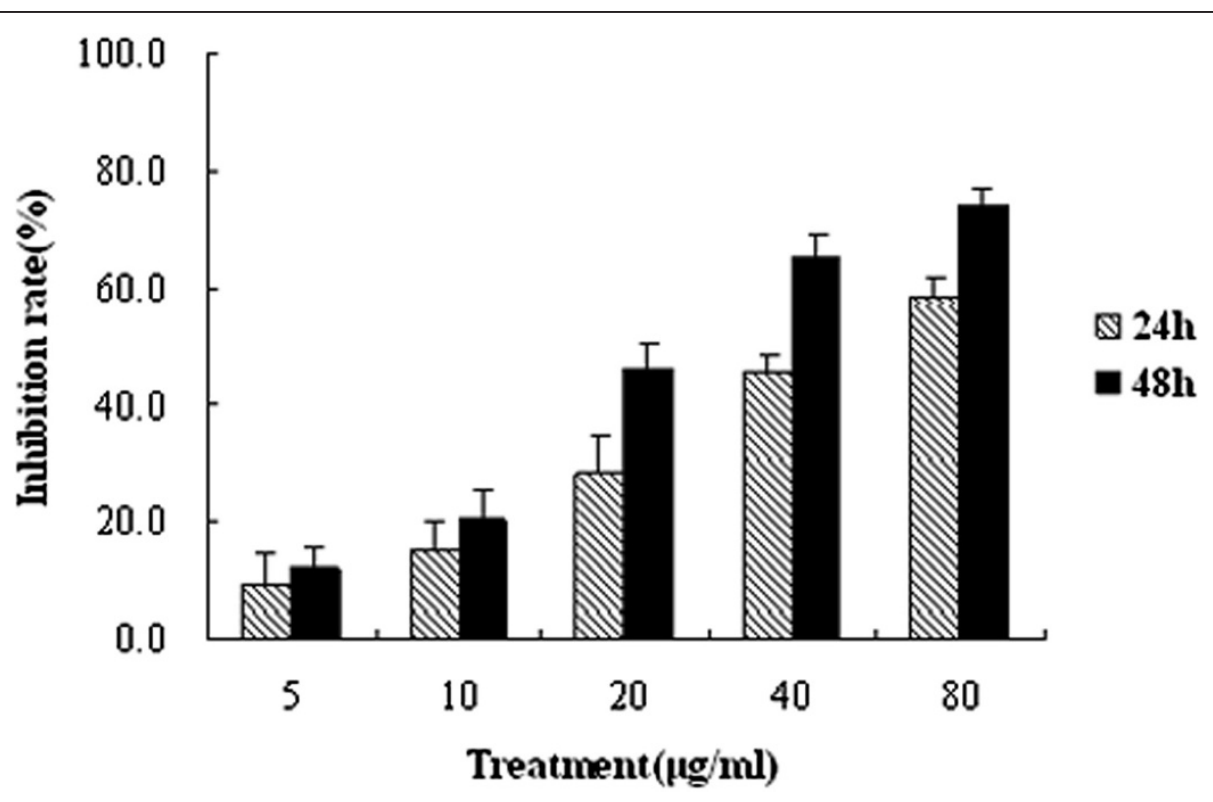

Figure 2 PG inhibits the viability of A549 cells in dose- and time-dependent manners. In the figure, Physcion 8-O- $\beta$-glucopyranoside abbreviated as PG. Cells were seeded in 96-well plates and treated on the following day with indicated concentrations of PG for 24 and 48 h, respectively, the cells viabilities were determined by MTT assay. 
significantly affected cell cycle distribution, leading to cell cycle arrest at $G_{2} / M$ phase. Cell amount at $G_{2} / M$ phase increased from $7.7 \%$ (medium group) to $14.6 \%$ (20 $\mu \mathrm{g} / \mathrm{mL}, \mathrm{PG}), 20.8 \%$ (40 $\mu \mathrm{g} / \mathrm{mL} \mathrm{PG),} \mathrm{and} \mathrm{even} \mathrm{up}$ to $36.9 \%(80 \mu \mathrm{g} / \mathrm{mL} P G)$. Cells in the $G_{1}$ or $S$ phase shifted concomitantly to the changes detected in $G_{2} / M$ (Figure 3). The results also showed that treatment of cells with $80 \mu \mathrm{g} / \mathrm{mL}$ PG resulted in cell cycle arrest at $\mathrm{G}_{2} / \mathrm{M}$ phase in a time-dependent manner. Cell amount at $\mathrm{G}_{2} / \mathrm{M}$ phase increased from $8.4 \%(12 \mathrm{~h})$ to $19.3 \%(24 \mathrm{~h})$, even

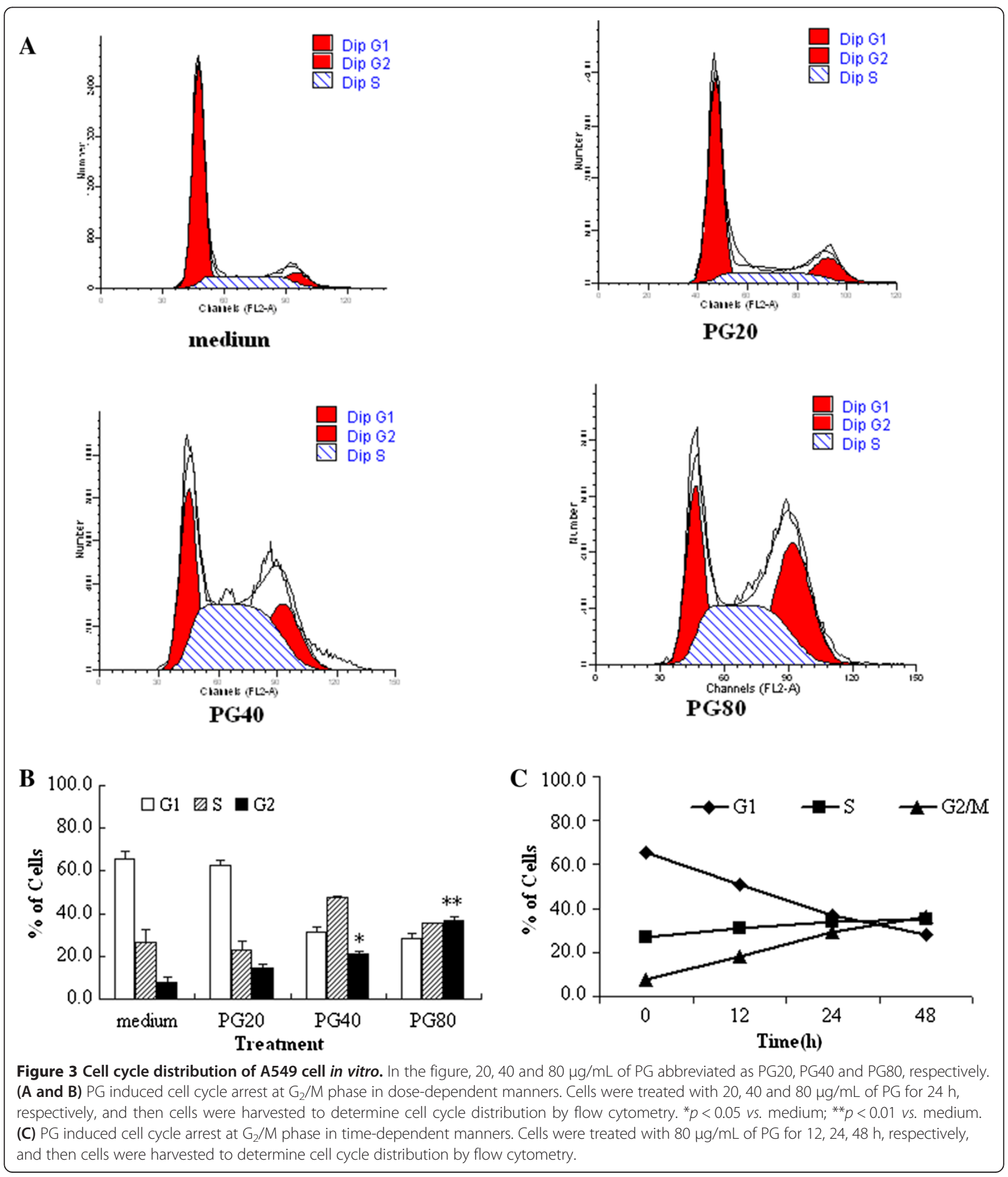


up to $36.5 \%$ (48 h). The results suggested the antitumor effect of PG was related to cell cycle arrest at the $G_{2} / M$ phase.

\section{Effect of PG on the expression of $\mathrm{G}_{2} / \mathrm{M}$ cell cycle} regulatory proteins

Our data showed that PG-mediated anti-proliferative effects were accompanied by cell cycle arrest at G2/M phase. Cell cycle progression through $\mathrm{G} 2 / \mathrm{M}$ is regulated principally by the sequential activation of the Cyclin B/Cdc2. To explore the mechanism by which PG induced the cell cycle arrest at the G2/M phase in A549 cells, we used western blot assay to determine if PG modulate the expression of G2/M cell cycle regulatory molecules. The results demonstrated that treatment of A549 cells with 20,40, $80 \mu \mathrm{g} / \mathrm{mL}$ of PG for $48 \mathrm{~h}$ resulted in a $0.6,0.34,0.08$ fold decrease in expression of Cyclin B1 and a 0.78, 0.49, 0.33 fold decrease of phospho-Cdc2 (Tyr15) compared to control group (Figure 4). On the other hand, total levels of Cdc2 remained largely unchanged after treatment (Figure 4). These data suggested decreased cyclin B1 and cdc2 protein expressions contributed to $\mathrm{G} 2 / \mathrm{M}$ arrest induced by PG in A549 cells.

\section{PG induced A549 cell apoptosis}

In order to make sure whether the anti-proliferative effect of PG on A549 cell was due to apoptosis, the flow cytometry analysis was used. Our results revealed PG could significantly increase apoptosis of the cells compared to medium. 20, 40 and $80 \mu \mathrm{g} / \mathrm{mL}$ of PG produced a $26.9 \%$, $53.7 \%$ and $70.72 \%$ of propidium iodide $(+)$ /annexin $\mathrm{V}(+)$ cells (necrosis/late apoptosis), respectively, However, the medium group only produced $4.86 \%$ of cells (necrosis/late apoptosis) (Figure 5A). To further confirm 20, 40 and $80 \mu \mathrm{g} / \mathrm{mL}$ of PG indeed increased apoptosis, Ac-DEVD$\mathrm{CHO}$, a caspase inhibitor [22], was used. The results further demonstrated PG in combination with Ac-DEVD$\mathrm{CHO}$ could partly reverse the anti-proliferative effect compared to PG-alone treatment group (Figure 5B).

\section{PG induce apoptosis via Caspase pathway}

It is well known that most cell apoptosis-inducing factors eventually cause cell apoptosis through the caspasemediated signal transduction pathway. Caspase 3 and caspase 7 is the executioner caspases in the caspase cascade that lead to apoptotic [22].

Bax is a well-known pro-apoptotic protein and Bcl-2 is an anti-apoptotic protein, the ratio of $\mathrm{Bcl}-2 / \mathrm{Bax}$ has a
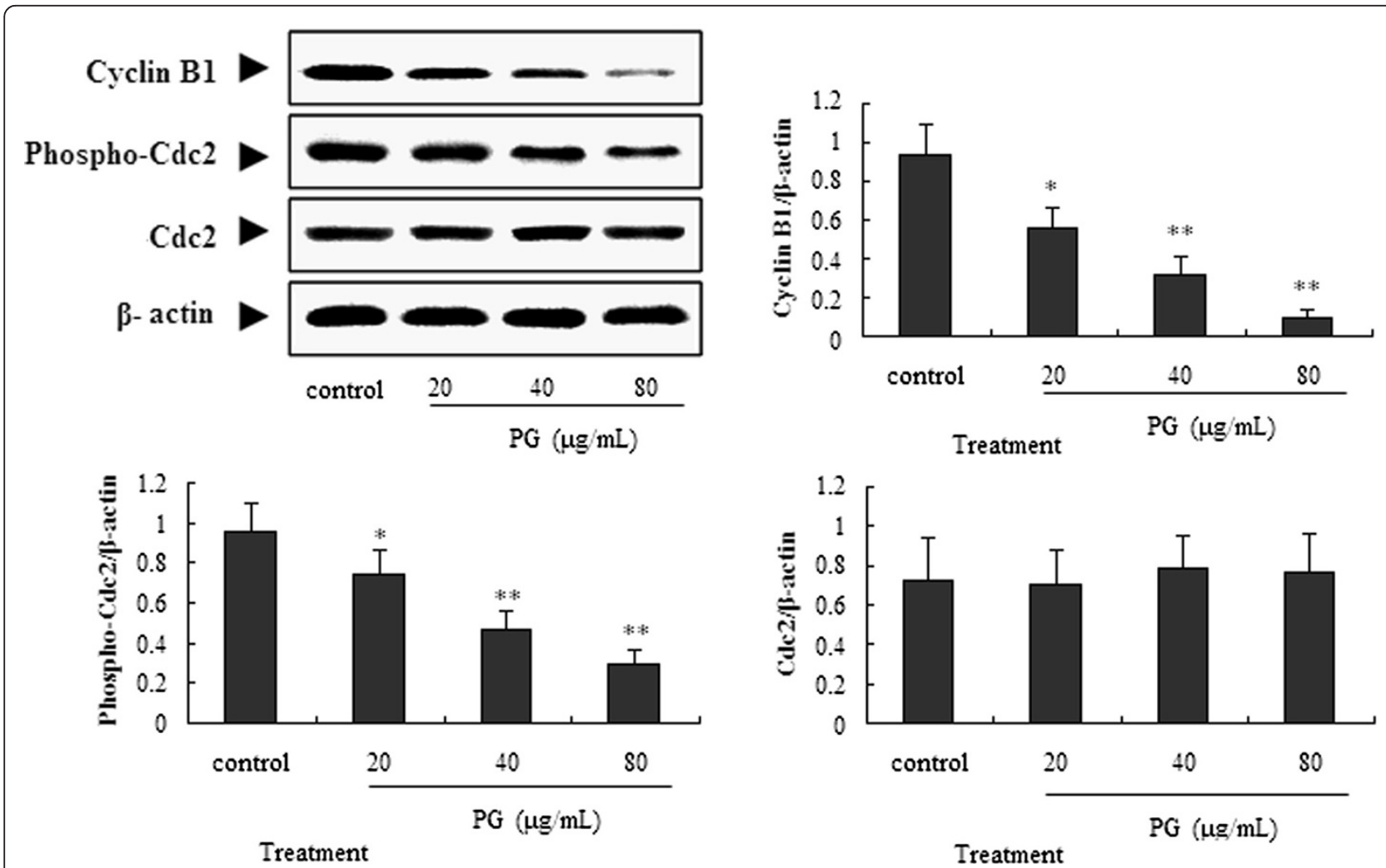

Figure 4 Effect of PG on the cyclin proteins of Cdc2 and cyclin B1. In the figure, 20, 40 and $80 \mu \mathrm{g} / \mathrm{mL}$ of PG abbreviated as PG20, PG40 and PG80, respectively. Physcion 8-O- $\beta$-glucopyranoside abbreviated as PG. A549 cells were treated with PG (20, 40 and $80 \mu \mathrm{g} / \mathrm{mL})$ for $48 \mathrm{~h}$, and then the cells were collected for western blot assay in vitro. 


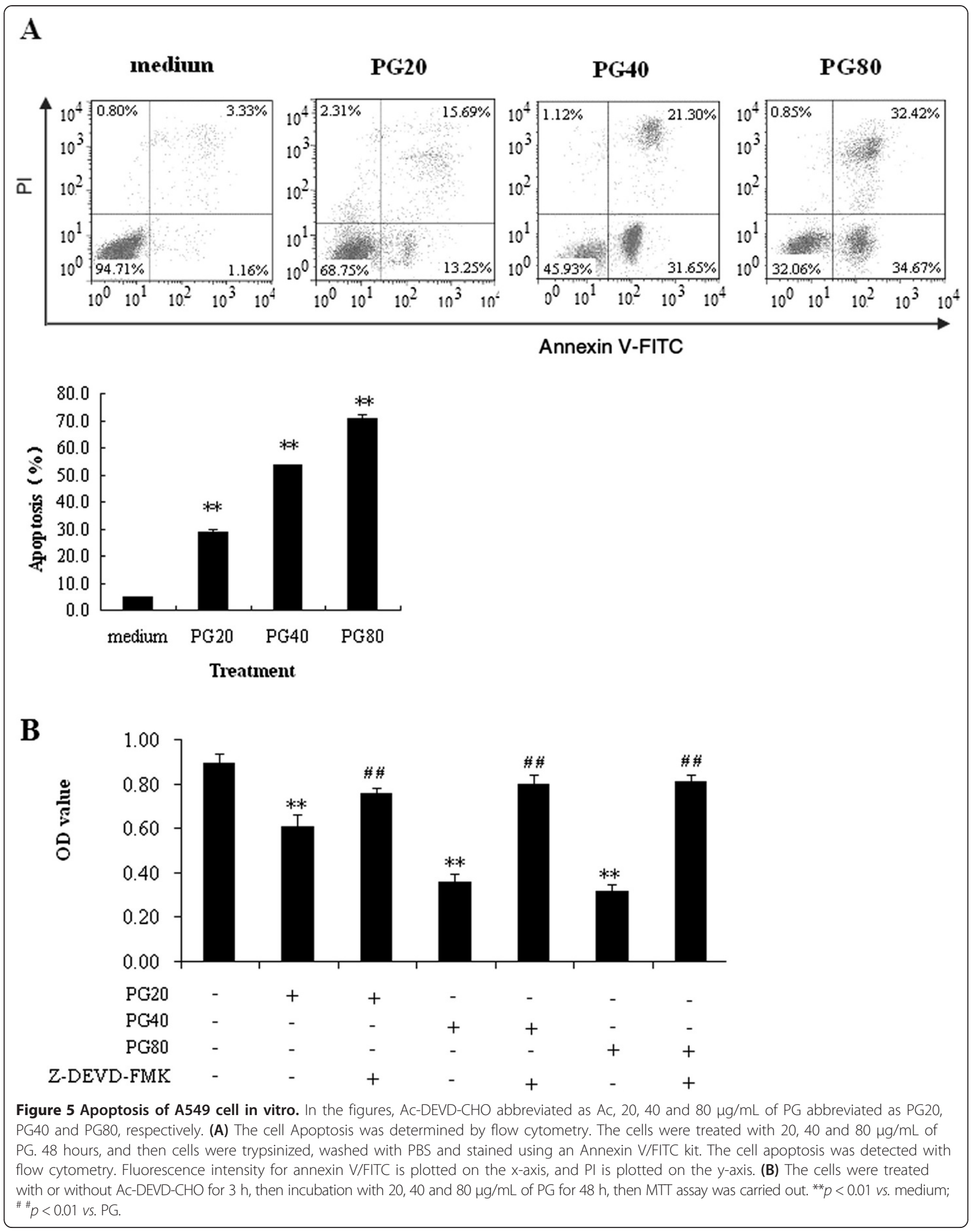


decisive role to induce apoptosis [23,24]. To determine whether the apoptosis was regulated by caspase-3, caspase-7, Bax and $\mathrm{Bcl}-2$ proteins, we measured the expression of caspase- 3 , caspase- 7 , Bax and $\mathrm{Bcl}-2$ proteins in A549 cells treated with 20, 40 and $80 \mu \mathrm{g} / \mathrm{mL}$ of PG using Western blot analysis. Our data showed that after 20, 40 and $80 \mu \mathrm{g} / \mathrm{mL}$ of PG treatment, the cleaved Caspase-3 were increased 2.1, 5.8, 7.2 fold, the cleaved caspase-7 were increased 2.8, 7.0, 9.6 fold, and the protein expression of Bcl-2 level was decreased, but the Bax expression level was increased, when compared to the medium group (Figure 6). Therefore, the ratio of Bcl-2/ Bax was significantly increased after PG treatment, when compared with the medium. All results showed that cell apoptosis is also a major reason of PG anti-proliferative effect, and the Caspase-3, Caspase-7, Bcl-2 and Bax are involved.

\section{Discussion}

Nowadays, cancer is recognized as a chronic and refractory disease that markedly affects patient quality of life. Furthermore, cancer is an important cause of substantial medical care expenditures. Currently, approximately $40 \%$ cancer patients with stage III or IV NSCLC currently can not be resected, and chemotherapy is the major treatment in such cancer patients [5]. However, the prolonged use of these drugs can induce the unbearable side-effects. Therefore, how to find the novel treatment strategies against NSCLC cancer with less adverse side-effects became a serious and urgent problem.

As a part of our continuing study regarding investigating the anti-cancer agents derived from TCMs, this study was designed to examine the effect of PG on cell proliferation, cell cycle, and apoptosis in A549 cells. To the best of our knowledge, this is the first report regarding anti-tumor activity of PG. Interestingly, the present study showed that PG significantly inhibited cell proliferation in dose-dependent manners and this inhibitory effect resulted from cell cycle arrest at G2/M phase. Additionally, we also found that exposure of A549 cells to PG resulted in an obvious increase in apoptosis, suggesting that apoptosis and cell cycle arrest contribute to growth inhibition in PG-treated A549 cells. G2 to M phase progression is regulated by a number of proteins
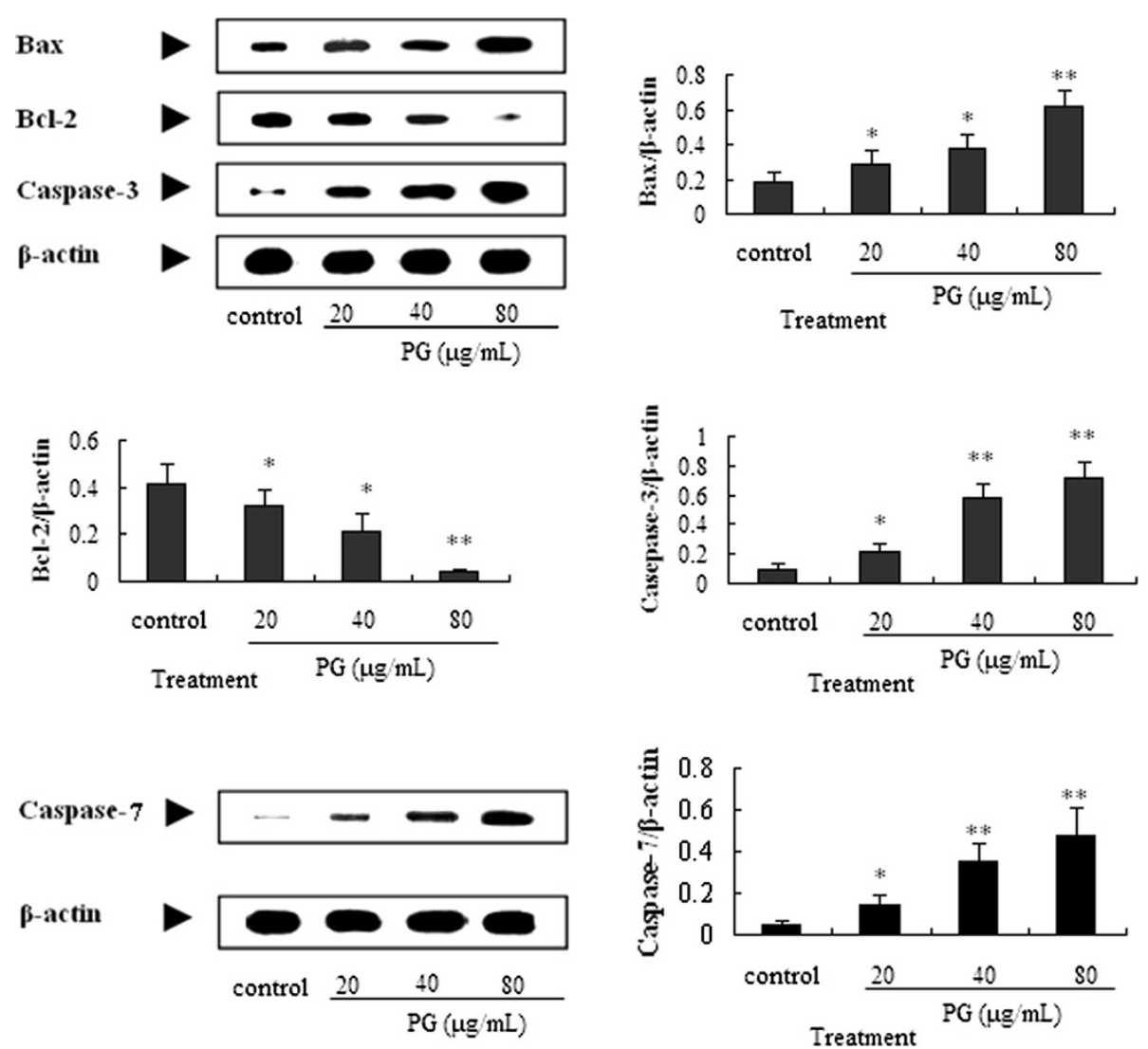

Figure 6 The protein expression of caspase-3, Bax, Bcl-2 and caspase-7 by western blot assay in vitro. In the figure, 20,40 and $80 \mu \mathrm{g} / \mathrm{mL}$ of PG abbreviated as PG20, PG40 and PG80, respectively. A549 cells were treated with 20,40 and $80 \mu \mathrm{g} / \mathrm{mL}$ of PG for $48 \mathrm{~h}$, then the cells were collected for western blot assay in vitro. ${ }^{*} p<0.05$ vs. control; ${ }^{* *} p<0.01$ vs. control. 
of the CDK/cyclin family; importantly, the activation of the $\mathrm{Cdc} 2 / \mathrm{Cyclin} \mathrm{B} 1$ complex is required for transition from $\mathrm{G} 2$ to $\mathrm{M}$ phase of the cell cycle [25]. To elucidate the mechanism by which PG-induced cell cycle arrest at G2/M phase, we determined the expressions of phosphoCdc2 (Tyr15) and Cyclin B1 in A549 cells treated with PG. The results of our present study showed that PG markedly down-regulated the expressions of Cyclin B1 and the phosphorylation of Cdc2 at Tyr15, suggesting that repression of cdc2 and Cyclin B1 is likely to be involved in PG-induced G2/M arrest. Collectively, the results of our study indicated that PG treatment could potentially inhibit the proliferation of A549 cells by cell cycle arrest at G2/M phase.

Apoptosis is one of the major mechanisms of cell death in response to cancer therapies, and caspases proteins play the key roles in the execution phase of apoptosis. Caspase 3 and caspase 7 are the executioner caspases in the caspase cascade that lead to apoptosis. Caspase- 3 is a caspase protein that interacts with caspase- 8 and caspase- 9 , encoded by the CASP3 gene Caspase- 3 has been activated in the apoptotic cell both by extrinsic (death ligand) and intrinsic (mitochondrial) pathways. The activated Caspase- 3 induces Caspase- 8 activation, then actives Bax. Bax activates Cyt c, and induces apoptosis. Our results showed that Caspase-3, caspase-7 and Bax expressions were up-regulated by treatment with PG, whereas the protein expression level of $\mathrm{Bcl}-2$ was down-regulated. These findings above demonstrate the mechanism by which PG exert their growth inhibitory effect, is related to induce A549 cells apoptosis through inducing caspases pathway and cell cycle arrest at $\mathrm{G} 2 / \mathrm{M}$ phase.

\section{Conclusions}

In conclusion, A549 cells viability was significantly inhibited by PG in vitro, in a dose- and time-dependent manner, and the possible mechanism may be related to cell cycle arrest at the $G_{2} / M$ phase, and apoptosis might be via the regulations of $\mathrm{Bax}, \mathrm{Bcl}-2$, Caspase-3 and Caspase-7. Consequently, the present results indicated that the PG is worthy for further exploration for lung cancer treatment, and more laboratory investigations are necessary to elucidate the mechanism of actions.

\section{Competing interests}

The authors declare that they have no competing interests.

\section{Authors' contributions}

XQC conceived and designed the experiment; XQC and YYP participated in the design, analysis, interpretation of the data, and wrote the manuscript. Both authors read and approved the final manuscript.

\section{Acknowledgements}

This study was supported by the National Natural Science Foundation of China (NSFC, No. 30801389).
Received: 13 September 2013 Accepted: 30 September 2014

Published: 6 October 2014

\section{References}

1. Siegel R, Naishadham D, Jemal A: Cancer statistics, 2012. CA Cancer J Clin 2012, 62(1):10-29.

2. Wen J, Fu JH, Zhang W, Guo M: Genetic and epigenetic changes in lung carcinoma and their clinical implications. Modern Pathol 2011, 24(7):932-943.

3. Liu Y, Sun WY, Zhang KT, Zheng HW, Ma Y, Lin DM, Zhang XY, Feng L, Lei WD, Zhang ZQ, Guo SP, Han NJ, Tong W, Feng XL, Gao YN, Cheng SJ: Identification of genes differentially expressed in human primary lung squamous cell carcinoma. Lung Cancer 2007, 56(3):307-317.

4. Alberg AJ, Ford JG, Samet JM, American College of Chest P: Epidemiology of lung cancer: ACCP evidence-based clinical practice guidelines ( $2^{\text {nd }}$ edition). Chest 2007, 132(3 Suppl):29S-55S.

5. You ZY, Zhao Y, Liu F, Zhang YD, Wang JJ: The radiosensitization effects of Endostar on human lung squamous cancer cells $\mathrm{H}-520$. Cancer Cell Int 2010, 10:17.

6. Zhao YY, Jiang WW, Li B, Yao Q, Dong JQ, Cen YY, Pan XC, Li J, Zheng J, Pang $X \mathrm{~L}$, Zhou H: Artesunate enhances radiosensitivity of human nonsmall cell lung cancer A549 cells via increasing NO production to induce cell cycle arrest at G2/M phase. Int Immunopharmcol 2011, 11(12):2039-2046

7. Tamura A, Hebisawa A, Hayashi K, Sagara Y, Fukushima K, Kurashima A, Yotsumoto H, Mori M, Komatsu H: Prognostic significance of thrombomodulin expression and vascular invasion in stage I squamous cell carcinoma of the lung. Lung Cancer 2001, 34(3):375-382.

8. Cragg GM, Grothaus PG, Newman DJ: Impact of natural products on developing new anti-cancer agents. Chem Rev 2009, 109(7):3012-3043.

9. Wang W, Li N, Luo M, Zu YG, Efferth T: Antibacterial activity and anticancer activity of Rosmarinus officinalis L. essential oil compared to that of its main components. Molecules 2012, 17(3):2704-2713.

10. Meng Z, Garrett CR, Shen Y, Liu L, Yang P, Huo Y, Zhao Q, Spelman AR, $\mathrm{Ng} C \mathrm{CS}$, Chang DZ, Cohen L: Prospective randomised evaluation of traditional Chinese medicine combined with chemotherapy: a randomised phase II study of wild toad extract plus gemcitabine in patients with advanced pancreatic adenocarcinomas. Brit J Cancer 2012, 107(3):411-416.

11. Peng $W$, Guo $L$, Zheng CJ, Zhang QY, Jia M, Jiang YP, Han T, Qin LP: Two new azaphilone alkaloids dimers from endophytic Chaetomium fusiform of the liverwort Scapania verrucosa Heeg. Biochem Syst Ecol 2012, 45:124-126

12. Han X, Yan DM, Zhao XF, Matsuura H, Ding WG, Li P, Jiang S, Du BR, Du PG, Zhu X: GHGKHKNK octapeptide (P-5 m) inhibits metastasis of HCCLM3 cell lines via regulation of MMP-2 expression in in Vitro and in Vivo studies. Molecules 2012, 17(2):1357-1372.

13. Jiang LL, Zhang SW, Xuan LJ: Oxanthrone C-glycosides and epoxynaphthoquinol from the roots of Rumex japonicus. Phytochem 2007, 68(19):2444-2449.

14. Ma JK, Liu Z, Lei JT, Ge SC: Study on the chemical constituents of Rumex japonicus Houtt. J Jilin Med Colle 2011, 32:133-134.

15. Belkin M, Fitzgerald DB: Tumor-damaging capacity of plant materials. I. Plants used as cathartics. J Natl Cancer Inst 1952, 13(1):139-155.

16. Zheng SQ, Chen WS, Tao ZY, Yuan Y, Li B, Zhao CZ: Study on the chemical constituents of Rumex japonicus Houtt. (I). Acad J Sec Mil Med Univ 2000, 21:910-912

17. Liu J, Xia ZT, Zhou GR, Zhang LL, Kong LY: Study on the chemical constituents of Rumex Patientia. J Chin Med Mater 2011, 34:893-895.

18. Li XL, Liu D, Liu X, Jiang WW, Zhou WY, Yan W, Cen YY, Li B, Cao GQ, Ding GF, Pang XL, Sun JG, Zheng J, Zhou H: CpG ODN107 potentiates radiosensitivity of human glioma cells via TLR9-mediated NF-kappaB activation and NO production. Tumour Biol 2012, 33(5):1607-1618.

19. Zhu W, Zhu D, Lu S, Wang T, Wang J, Jiang B, Shu Y, Liu P: miR-497 modulates multidrug resistance of human cancer cell lines by targeting BCL2. Med Oncol 2012, 29(1):384-391.

20. Shapiro Gl, Harper JW: Anticancer drug targets: cell cycle and checkpoint control. J Clin Invest 1999, 104(12):1645-1653.

21. Choi EJ, Oh HM, Wee H, Choi CS, Choi SC, Kim KH, Han WC, Oh TY, Kim SH, Jun CD: Eupatilin exhibits a novel anti-tumor activity through the induction 
of cell cycle arrest and differentiation of gastric carcinoma AGS cells. Differentiation 2009, 77(4):412-423.

22. Cohen GM: Caspases: the executioners of apoptosis. Biochem J 1997, 326(Pt 1):1-16.

23. Strasser A, Huang DC, Vaux DL: The role of the bcl-2/ced-9 gene family in cancer and general implications of defects in cell death control for tumourigenesis and resistance to chemotherapy. Biochim Biophys Acta 1997, 1333(2):151-178.

24. Gao N, Budhraja A, Cheng S, Yao H, Zhang Z, Shi X: Induction of apoptosis in human leukemia cells by grape seed extract occurs via activation of c-Jun NH2-terminal kinase. Clin Cancer Res 2009, 15(1):140-149.

25. Sherr CJ: Cancer cell cycles. Science 1996, 274(5293):1672-1677.

doi:10.1186/1472-6882-14-377

Cite this article as: Xie and Yang: Anti-proliferative of physcion 8-O- $\beta$ glucopyranoside isolated from Rumex japonicus Houtt. on A549 cell lines via inducing apoptosis and cell cycle arrest. BMC Complementary and Alternative Medicine 2014 14:377.

\section{Submit your next manuscript to BioMed Central and take full advantage of:}

- Convenient online submission

- Thorough peer review

- No space constraints or color figure charges

- Immediate publication on acceptance

- Inclusion in PubMed, CAS, Scopus and Google Scholar

- Research which is freely available for redistribution 